Hewitt, E. J. (1956). In Plant Analysis \& Fertilizer Problems. [P. Prévot, editor.] Paris: Institut de Recherches pour les Huiles et Oléagineux.

Hill-Cottingham, D. G. \& Lloyd-Jones, C. P. (1958). Plant $E^{*}$ Soil, 9, 189.

Kardos, L. T. (1955). In Chemistry of the Soil. [F. E. Bear, editor.] New York: Reinhold Publishing Corp.

Kurtz, L. T. (1953). In Soil and Fertilizer Phosphorus in Crop Nutrition. [W. H. Pierre and A. G. Norman, editors.] New York: Academic Press Inc.

Lundegårdh, H. (1951). Leaf Analysis. London: Hilger \& Watts Ltd.

Mann, P. J. G. \& Quastel, J. H. (1946). Nature, Lond., 158, I54.

Marshall, C. E. (1957). In Mineral Nutrition of Plants. [E. Truog, editor.] Madison, Wis.: University of Wisconsin Press.

Morris, H. D. (1949). Proc. Soil Sci. Soc. Amer. 13, 362.

Olsen, R. A. \& Peech, M. (1960). Proc. Soil Sci. Soc. Amer. 24, 257.

Quastel, J. H. (1963). In Plant Physiology. Vol. 3. Inorganic Nutrition of Plants. [F. C. Steward, editor.] New York and London: Academic Press Inc.

Reuther, W. (cditor) (196r). Plant Analysis and Fertilizer Problems. Publ. no. 8. Washington: American Institute of Biological Sciences.

Reuther, W. \& Smith, P. F. (1954). In Fruit Nutrition. [N. F. Childers, editor.] New Brunswick, NJ: Horticultural Publications Rutgers University.

Salmon, R. C. (1962). Magnesium relationships in some British soils. Ph.D. Thesis, University of London.

Schofield, R. K. (1955). Soils Eீ Fert. 18, 373.

Smith, P. F. (1962). Annu. Rev. Pl. Physiol. r3, 81.

Steenbjerg, F. (1954). Plant \& Soil. 5, 226.

Tinker, P. B. (1964). F. Soil Sci. r5, 35.

Wallace, A. (editor) (1962). A Decade of Synthetic Chelating Agents in Inorganic Plant Nutrition. Los Angeles, Calif.: A. Wallace.

Wallace, T., Hewitt, E. J. \& Nicholas, D. J. D. (1945). Nature, Lond., 156, 778.

Wiklander, L. (1955). In Chemistry of the Soil. [F. E. Bear, editor.] New York: Reinhold Publishing Corp.

Woodruff, C. M. (1955). Proc. Soil Sci. Soc. Amer. 19. 36.

\title{
Effects of organic manures on soils and crops
}

\section{By A. H. Bunting, Department of Agricultural Botany, University of Reading}

All soils which carry crops or vegetation contain organic matter, which consists of or is derived from the plants, animals and micro-organisms which live or have lived in or on the soil. Agricultural and especially horticultural soils contain also organic matter derived from whatever organic manures have been incorporated in the soil. The quantities of organic matter in soils range from below $\mathrm{r} \%$ (dry weight) in the soils of arid and semi-arid regions to over $80 \%$ in organic soils such as peats in which acidity, waterlogging or other conditions have checked the oxidation of the organic materials. Many British agricultural soils contain $1-3 \%$ of organic matter. The amount of organic material in the soil represents the equilibrium between additions (parts of plants and animals and their excreta, crop residues and organic manures) and losses, mainly by biological oxidation, and for any particular, and more or less stable, set of technological or ecological circumstances it tends to a steady value.

On the Broadbalk plots at Rothamsted, on a heavy clay-with-flints soil, plots which have received no manure, or mineral fertilizers only, for over I 20 years, contain about $2 \%$ of organic matter; in those which have received both mineral and nitrogen fertilizers the larger amounts of crop residues have raised this figure to about $2.4 \%$; and the plot to which 14 tons per acre of farmyard manure has been added each year 
contains about $5 \%$ of organic matter (Table $\mathrm{I}$ ). When forest soils, with large quantities of organic matter, are brought into cultivation, the content of organic matter in them falls until a new equilibrium is reached; and conversely the organic matter content of arable soils can be increased by management, as the Broadbalk figures show.

On an acre the dry weight of soil to plough depth is conventionally taken as I000 tons. Therefore $2 \cdot 5 \%$ of organic matter represents 25 tons; I0 tons/acre fresh weight of farmyard manure contains about $1 \frac{1}{2}$ tons organic matter (dry weight), so that it adds only about $6 \%$ to the organic matter already present in an acre. Nevertheless such an addition, though proportionately small, may have very considerable effects on crop yield. This paper presents an account of some recent, and some not so recent, work on these effects and how they are produced. This has been a matter of considerable controversy, among agriculturists as well as among people interested in nutrition, and as usual in technical controversies the heat generated has been inversely related to the quantity of light. I do not propose here to consider, except in passing, the nutritional value of crops which have been manured with organic manures: I shall deal mainly with effects of organic manures on the yield of crops and on measurable attributes of soils.

By 'organic manures' I do not mean such materials as dried blood, hoof and horn and other organic materials which are used, at rates of up to a ton per acre, primarily for the sake of the fairly readily available $N$ they contain: I am concerned with the so-called bulky organic manures-chiefly farmyard manure (FYM), composts and sewage sludge, of which several tons per acre or more are given at each application, and in which the concentration of plant foods is of the order of a few \% only on dry weight.

\section{The effects of organic manures on crop yields}

Green plants are autotrophic: that is to say they can be grown to healthy and normal maturity in sand or water cultures in which they are supplied with inorganic salts, water, air, and light only. Organic matter is not essential for the growth of green plants: the humus theory of plant nutrition was abandoned by chemists and by most botanists well over a century ago. Consequently the nature of the effects of FYM has been a central topic in agricultural research for over 120 years. The famous Broadbalk experiment, started in 1843 , compares the yield of wheat on plots which receive I4 tons FYM per acre per year with that of plots receiving no manure, the chemical equivalent of the ash of FYM, or the ash equivalent plus a range of amounts of $\mathrm{N}$ supplied in different forms. Although the soil of the FYM plot is now very different from that of the other plots, as the figures for organic matter show, as good or better yields have been obtained on Broadbalk for many years with fertilizers as with FYM ('Table I) and it has become evident that the effect of FYM on yield is largely due to the plant nutrients it supplies, particularly $\mathrm{N}$. The yield of wheat on Broadbalk is not related to the content either of organic matter or of total $\mathrm{N}$ in the soil.

All subsequent work has confirmed that in general the supply of plant nutrients is an important component of the action of bulky organic manures. FYM, which 
Table I. Organic matter and total $N$ of soil on Broadbalk strips, and corresponding long-term average yields of wheat

$\begin{array}{lccc} & \begin{array}{c}\text { Total } \\ \text { N }(\%)\end{array} & \begin{array}{c}\text { Organic } \\ \text { matter }(\%)^{*}\end{array} & \begin{array}{c}\text { Yield, } \\ \text { (cwt/acre) } \dagger\end{array} \\ \text { No manure } & 0.10 & 2.0 & 7 \\ \text { N-P-K fertilizers } & 0.12 & 2.4 & 20 \\ \text { Farmyard manure } & 0.25 & 5.0 & 19\end{array}$

*Total $\mathrm{N} \times 20$. Organic-matter content cannot easily be determined accurately in the Broadbalk soils by loss on ignition, since carbonate $\mathrm{CO}_{2}$ and combined water are lost at the same time. Total $\mathrm{N}=$ about $5 \%$ of organic matter in Broadbalk soils. Total $\mathrm{N} \times 20$ is the most reliable method for routine estimation of organic matter in these soils.

†Average over many years.

incorporates the faeces and urine of stock together with straw, contains around $2 \% \mathrm{~N}, 0.7 \%$ phosphorus and $1.7 \%$ potassium on the dry-matter basis ('Table 2); sewage sludge contains more $N$, and may contain more $P$, but has very little $K$; composts made with straw and other sources of $\mathrm{N}$ have less $\mathrm{P}$ and $\mathrm{K}$, but much the same amount of $\mathrm{N}$, as FYM.

Table 2. Composition of bulky organic manures ( $\%$ dry matter)

$\begin{array}{lllll}\text { Farmyard manure } & 64 & 2 \cdot 2 & 0 \cdot 7 & 1 \cdot 7 \\ \text { Undigested sewage sludge } & 51 & 2 \cdot 4 & 0.6 & 0.3 \\ \text { Digested sewage sludge } & 44 & \mathbf{2} \cdot 6 & 1 \cdot 0 & 0.3 \\ \text { Straw-sludge compost } & \mathbf{5 3} & \mathbf{2 \cdot 1} & 0.7 & 0.6\end{array}$

The total quantities of plant foods and organic matter supplied by applications of these materials at acceptable commercial rates ( 2 tons fresh FYM or straw-sludge compost per acre, sludges at $7 \frac{1}{2}$ tons dry matter/acre) are shown in Table 3 .

Table 3. Amounts of organic matter and plant foods per acre in standard applications of bulky organic manures

$\begin{array}{lcccc} & \begin{array}{c}\text { Organic } \\ \text { matter } \\ \text { (tons) }\end{array} & \begin{array}{c}\mathrm{N} \\ \text { (cwt, }\end{array} & \begin{array}{c}\mathbf{P} \\ \text { as elements) }\end{array} \\ \text { Farmyard manure } & \mathbf{1} \cdot 9 & 1.4 & 0.4 & \mathbf{K} \\ \text { Undigested sewage sludge } & 3.8 & 3.6 & 0.9 & 0.3 \\ \text { Digested sewage sludge } & 3.3 & 3.9 & \mathrm{I} \cdot 4 & 0.5 \\ \text { Straw-sludge compost } & 1.9 & 1 \cdot 4 & 0.5 & 0.4\end{array}$

The quantities of $\mathrm{N}$ supplied in these applications are larger (and by the sludges very much larger) than would be given by the usual dressings of fertilizer to farm crops; the quantities of $\mathrm{P}$ are of the same order as are given in fertilizers, and (except for FYM) those of $\mathrm{K}$ are less. Of course by no means all of these amounts of plant foods are immediately available to crops. It has been estimated, for example, that the effective contribution to crop nutrition of 12 tons FYM/acre is about $0.4 \mathrm{cwt} \mathrm{N}$, $0.2 \mathrm{cwt} \mathrm{P}$, and 0.75 cwt $\mathrm{K}$ (as elements), so that most of the $\mathrm{K}$, but much less of the 
$\mathrm{N}$ and $\mathrm{P}$, are available in the year in which they are applied. An incompletely decomposed FYM or compost can in fact diminish the supply of $N$ to the crop because all its own $\mathrm{N}$, and some soil $\mathrm{N}$, is used by the micro-organisms which rot the straw.

Estimates of this sort are obtained from factorial experiments, in which the manures and fertilizers supplying $\mathrm{N}, \mathrm{P}$ and $\mathrm{K}$ are tested separately and in all combinations. In such experiments the effects of the main nutrients in the organic manures can be assessed. They are consequently much more informative than simple comparisons of organic manures and fertilizers, in which the outcome will depend very largely on the rates chosen. If the effect of a fertilizer supplying $\mathrm{N}$ is decreased when a manure is also given, the manure is probably supplying N. Experiments of this sort (Cooke \& Garner, 1954; Bunting, 1963) have shown that FYM, if it is properly made and handled, supplies $\mathrm{N}$ and $\mathrm{P}$, and particularly $\mathrm{K}$; sewage sludges provide $\mathrm{N}$ and (except for some sludges from industrial areas) $\mathrm{P}$, but no $\mathrm{K}$, since all the soluble $\mathrm{K}$ of the sewage is lost in the purified effluent; straw-sludge composts, like FYM, supply $\mathrm{N}, \mathrm{P}$ and $\mathrm{K}$, since the $\mathrm{K}$ in the straw makes up to some extent for the deficiency of $\mathrm{K}$ in the sludge.

When fertilizers containing $\mathrm{N}, \mathrm{P}$ and $\mathrm{K}$ are given, at normal commercial rates, the effects of organic manures are therefore considerably decreased. Table 4 shows this for thirty-six experiments on potatoes; the results of another thirty-six experiments on a range of other crops were essentially similar (Bunting, I963).

Table 4. Effect of fertilizer $(N-P-K)$ on responses of potatoes to organic manures (tons per acre, numbers of experiments in parentheses)

\begin{tabular}{|c|c|c|c|}
\hline & $\begin{array}{l}\text { Farmyard } \\
\text { manure } \\
(30)\end{array}$ & $\begin{array}{l}\text { Sewage } \\
\text { sludge } \\
(36)\end{array}$ & $\begin{array}{l}\text { Straw-sludge } \\
\text { compost } \\
\text { (19) }\end{array}$ \\
\hline $\begin{array}{l}\text { Without fertilizer: } \\
\text { No organic manure } \\
\text { With organic manure }\end{array}$ & $\begin{array}{l}5 \cdot 4 \\
8 \cdot 7\end{array}$ & $\begin{array}{l}6 \cdot 4 \\
7 \cdot 5\end{array}$ & $\begin{array}{l}5 \cdot 2 \\
7 \cdot 7\end{array}$ \\
\hline Response to organic manure & $3 \cdot 3 \pm 0.44$ & $I \cdot 2 \pm 0 \cdot 27$ & $2.5 \pm 0.56$ \\
\hline $\begin{array}{l}\text { With fertilizer: } \\
\text { No organic manure } \\
\text { With organic manure }\end{array}$ & $\begin{array}{r}8.7 \\
10.5\end{array}$ & $\begin{array}{l}8 \cdot 8 \\
9.1\end{array}$ & $\begin{array}{l}8 \cdot \mathrm{I} \\
9 \cdot 8\end{array}$ \\
\hline Response to organic manure & $1 \cdot 7 \pm 0.29$ & $0.4 \pm 0.17$ & $1 \cdot 7 \pm 0 \cdot 34$ \\
\hline Effect of fertilizer on response to organic manure & $-\mathrm{r}-6$ & 0.8 & -0.8 \\
\hline
\end{tabular}

Where no fertilizer was given, FYM raised yield per acre from 5.4 to 8.7 tons; the effect of compost was less (from 5.2 to $7 \cdot 7$ tons) and that of sludge smaller still (from 6.4 to 7.5 tons). Fertilizer alone raised yields to $8-9$ tons, and FYM and compost then gave an extra $I \cdot 7$ tons, whereas sludge gave less than 0.4 tons only. The effect of sewage sludge was plainly largely due to the nutrients it contained; dung and compost on the other hand were able to increase the yields further even when fertilizer had been given.

Now, the rates at which the fertilizers were applied in these experiments (as in all others that have been published) were very much lower than the optimum rates for 
yield. It is consequently not possible to say, when yield is increased by an organic manure in the presence of N-P-K fertilizer, that the effect is due to some complex action rather than to the supply of additional nutrients. The FYM and compost may have increased the yield by supplying extra potash, to which the potato, like other Solanaceae, responds well, and which the sludge could not supply.

Even when complete fertilizer was also given, the yield per acre with sludge ( 9.1 tons) was less than with FYM (10.5 tons) or compost ( 9.8 tons). In the experiments taken as a whole, the effects of FYM or compost on potato yields were generally greater than those of sludge, and they increased with increasing doses, whereas those of sludge did not. The results suggested, though they could not prove, that although a great deal of the effect of the organic manures was associated with the direct supply of nutrients, since it could be matched with fertilizers, there was something special about the strawy materials.

This suggestion was reinforced by a study of the results of individual trials. The potato experiments from which these data came were part of a series of 113 experiments (Bunting, 1963) conducted on fifty-six sites in eight consecutive seasons. In forty-two of these experiments, on twenty-nine sites, one or more of the organic manures significantly increased the yield in the presence of fertilizer. In eleven of these experiments (on ten sites) it was possible to demonstrate with some certainty that an organic manure had done something other than supply nutrients; and all these effects, without exception, were given by strawy manures. It seems that it is not organic matter as such which is important, but organic matter in particular forms. Of the crops tested, red beet responded particularly well to strawy manures, and also to potash. As to the soils, all ten were light and tended to compact in dry weather. We shall return to these special effects.

An interesting effect of manuring has been found on the hill sands of Ukiriguru, in Tanganyika. There, a dressing of 7 tons/acre of compost affected yields of cotton for about 14 years, long after the organic matter itself had disappeared (Empire Cotton Growing Corporation, 1958). Compost seems to improve the supply to the crop of calcium and phosphate in these phosphate-deficient soils. The compost seems also to have made the soil less acid, and this appears to have altered the availability of the soil phosphate*. This is a complex effect, but there are many other ways in which organic manures can affect the supply of plant foods to crops. Organic manures may supply nutrients which fertilizers do not, such as minor elements and perhaps magnesium and sulphur; and they can have other effects on nutrient supply, by protecting $\mathrm{N}$ from leaching and $\mathrm{P}$ from being immobilized by reactions with the soil. The nutrients in an organic manure which is ploughed in may be available in dry weather when those in fertilizer nearer the surface of the soil are not.

It may be useful to record here that recent work shows that although grass leys also add considerably to the content of organic matter in the soil, their effects on yield are in most instances due largely to changes in the availability of plant nutrients. At the Grassland Research Institute, at Hurley, Berks, grass leys affect succeeding wheat,

\footnotetext{
*This work has not been formally written up, but it has been reported from time to time in progress reports of which the latest is Empire Cotton Growing Corporation, I 964.

24 (I) 3
} 
kale and barley entirely by accumulating or conserving $N$ : their effects on the test crops are closely correlated with increases in the amounts of mineralizable $\mathrm{N}$ in the soil (Clement \& Williams, I965). The Rothamsted and Woburn ley fertility experiments also show that a large part of the effect of the ley is due to the accumulation or conservation of plant nutrients (Cooke, 1963); at neither farm do the results suggest that ley farming is essential to maintain the productivity of arable soils, provided fertilizers are correctly used, and the special needs of leys for potash (especially when they are used for hay and silage) are not forgotten. The ley fertility experiments conducted at the Experimental Husbandry Farms of the Ministry of Agriculture appear to have given generally similar results. There is a tropical example also: the grass fallows which have so profound an effect on crop yields in Uganda improve the availability of $\mathrm{N}$, and (probably through effects on $\mathrm{pH}$ similar to those of compost at Ukiriguru) of phosphate as well.

Though many measurements have been made of the effects of organic manures on yield, I know of no modern studies of their effects on the quality of the produce, though there are of course many opinions. In many experiments, manures, fertilizers or other means of increasing yield increase the amount of produce without appearing to alter its kind very much. On the other hand, in many horticultural crops (for example lettuce or beetroot), a treatment may bring the crop to a marketable size at an earlier age, so that the produce consists of physiologically younger material, which contains less fibre and more sugar, and is, perhaps, more active metabolically also. Organic manures have no monopoly of such effects: potash can produce them in beetroot and $\mathrm{N}$ fertilizer in lettuce. Samples from a carrot crop grown in an experiment at Hersham in 1945 were assayed for vitamin content at the Human Nutrition Research Unit of the Medical Research Council. For the most part manuring did not affect composition, but FYM, which had considerably increased the yield, significantly increased the carotene content.

To summarize, the effects of organic manures on crops are often important but, like those of leys, they are largely associated with changes in the supply of nutrients. Nevertheless, there is good evidence that on some special soils, they have special effects on crop growth. For an analysis of these, we must consider in more detail the nature of organic matter in the soil.

\section{Organic matter in the soil}

The organic matter in an agricultural or horticultural soil consists of a wide range of materials-roots and other plant parts, fungi, bacteria and animals, and their excreta, and the plant and animal materials contained in whatever organic manures have been added to the soil. The organisms involved may be alive, dead, or more or less decomposed by other organisms. Innumerable organic compounds, many of them characteristic of micro-organisms, can be isolated from the soil organic matter, and various methods of fractioning the complex are commonly used, but we do not yet appear, nor should we expect, to have any simple chemical means of characterizing the soil organic matter as a whole. The organic matter complex is the seat of important biological activity. Whenever the temperature and water content 
are suitable, carbon is lost from it, as a product of the respiration of the organisms which form part of it or live in and on it. Consequently, in time, if there are no new additions of raw organic matter, carbohydrate substrates are used up and organisms which can obtain energy from more complex molecules become more prominent. As a result $\mathrm{N}, \mathrm{P}$ and other nutrient elements are released or excreted from the system in forms which can be taken up by higher plants or can be leached by water percolating down the profile. In terms of crude composition, the organic matter tends to a $\mathrm{C}: \mathrm{N}: \mathrm{P}$ ratio of roughly $100: 10: \mathrm{I}$.

Organic matter in the soil is a storehouse and workshop of plant foods, particularly $\mathrm{N}$, and this is particularly important in intensively cropped horticultural soils. The organic matter has several other significant attributes. The material of the organic complex has a high cation exchange capacity, and so can increase the quantity of ammonia and bases which can be held in the soil. Numerous physiologically active organic compounds occur in soil organic matter (Whitehead, 1963 ), but there is no agronomic evidence that they affect the yields of crops. The water-holding capacity of organic matter in the soil is considerable, but in most mineral soils the effect of this is usually not large, since the proportion of organic matter in the soil is small. On most soils, the direct effect on the water storage capacity of the soil of the quantities of organic matter added in normal manuring is negligible.

At Hersham, Surrey, during the $4^{\text {th }}$ year (1947) of an experiment on a series of horticultural crops on a sandy soil, H. L. Nixon determined the water content of the top 6 in. of the soil on a number of occasions during May and June (Bunting, 1963). Where no organic manure had been given, the average water content was $9.8 \%$; dung and straw-sludge compost raised it to $1 \mathrm{r} \%$, and on sludge plots it was $12 \cdot 2 \%$. The corresponding quantities of extra water, in the top $12 \mathrm{in}$. of the soil, represent 0.2 and $0.5 \mathrm{in.}$ on the strawy-manure and sludge plots respectively, enough for the evaporation needs of not more than $\mathrm{I}^{\circ} 5$ and 4 average summer days. In the lettuce crop which occupied the plots in 1947 , sludge had no effect on the yield of the crop, which was greatly improved by FYM and by straw-sludge compost (as well as by potash). The action of the manures on the crop was therefore not associated with their effect on the water content of the soil.

Organic materials have important effects on the structure of the soil. The waterstable crumbs which are a feature of many soils are produced by the mechanical action of roots and of soil animals, and they are held together largely by organic substances produced by the living organisms in the soil, probably in some special relation to the clay fraction. Organic manuring can consequently increase the proportion of water-stable crumbs: on Broadbalk the proportion of these crumbs larger than $0.5 \mathrm{~mm}$ diameter has been raised by manuring from 28 to $55 \%$, but as we have seen the absence of these extra crumbs does not affect the yield, provided suitable dressings of fertilizer are given.

In the same way, though leys at Hurley increase the percentage of water-stable crumbs, the increases bear no statistical relation to the effects on the yield of subsequent crops, which appear to be associated more or less completely with increases in the supply of available N. Generally, though some exceptions are reported, improve- 
ments in the proportion of water-stable crumbs produced by the synthetic soil conditioner Krilium (Monsanto Co. Ltd) have not been matched by increases in the yields of crops (cf. Haworth \& Nelder, 1954, 1955). It is possible (for example on the heavy clays or the light sands of the Sudan) to achieve very satisfactory yields on soils which are apparentiy structureless when they are wet and whose content of organic matter is below $1 \%$. An increase in the percentage of water-stable crumbs can, however, improve the mechanical properties of the soil so that it is easier to work in wet weather, and it can also improve the conditions in the seed bed, for germination and the growth of seedlings. At these stages the transpiring surface of the crop is negligible, so that oxygen cannot be drawn into the soil by the withdrawal of water in transpiration, and it is consequently important that oxygen should be able to diffuse freely into the soil when it is wet. This is belped by the increase in the volume of large pores which crumb structure provides. The crumbs can also protect soluble nutrients from leaching: the water passes round the crumbs rather than through them. On the whole, however, it seems that the importance of water-stable crumbs for established crops may have been exaggerated, and there is certainly no general agronomic evidence that any important part of the action of organic manures on crop yields depends on increases in the proportion of water-stable crumbs.

We can now return to the special soils mentioned earlier on which effects of organic manures can be demonstrated which do not appear to be related to the supply of plant nutrients. All these soils appear to contain large proportions of silt or fine sand, and when they are wet, they tend to pack into minimum volume in such a way that the volume of the pores (the spaces between the particles), is much decreased. In this state they become compacted when they dry, so that plant roots cannot freely grow through them, and they contain less readily available water (that which is held at low tension in larger pores). Such soils are thought to occupy about 10\% of the arable acreage of England.

Very fortunately, the National Vegetable Research Station at Wellesbourne, near Warwick, is sited on such a soil. At Wellesbourne, a long-term experiment has shown that the supply of nutrients is only in part the reason for the very marked responses of vegetable crops there to FYM (Haworth, I960). The soil at Wellesbourne contains $53 \%$ coarse sand, $28 \%$ fine sand, $10 \%$ silt, and $9 \%$ of clay (Salter \& Haworth, $196 \mathrm{r}$ ), and it compacts severely in dry weather. After 9 years, during which 20 tons of FYM per acre was applied to each crop and incorporated by rotavating (other methods of incorporation gave similar but smaller effects) the available water capacity (per unit of volume) in the top 6 in. of the soil had increased from 0.89 to $\mathrm{I} \cdot 5 \mathrm{I}$ in., and most of this extra water was held at low tension and was therefore readily available to plants. The moisture content of the soil at field capacity ( 0.05 atm tension) is now $22 \%$ on FYM plots and $14 \%$ on others (Salter \& Williams, I 963 ). A difference as large as this is not a direct consequence of the accumulation of material of higher waterholding capacity. The FYM has probably altered the geometry of the soil, so that it cannot pack as it did before (the apparent sp. gr. in December I 96 I was I. 57 on FYM plots and $\mathrm{r} \cdot 70$ on other plots), and it has increased the volume of larger pores.

The next problem was to find means of characterizing the special soils which tend 
to compact and on which strawy organic manures may be expected to produce special effects. This was a new problem: work on water-stable crumbs provided a measure of structure that is stable under artificial laboratory conditions; the measure now required was one of structure which is unstable in the field. Williams \& Cooke (196r) at Rothamsted investigated this problem and have provided some useful means of measurement. They used, among others, clay and sandy soils which had carried arable (mostly annual) crops continuously with and without dressings of FYM, or had been under grass, and they measured pore sizes, the stability of aggregates when the soils were wetted, the pore size distributions, and the mechanical strength of dried clods. The sandy soils become so closely packed under continuous cultivation that checks to root growth are likely (few or no pores larger than 200 $\mu \mathrm{m})$. FYM or grass increase the proportion of large pores (14-16\% of pore space $>200 \mu \mathrm{m})$. The aggregates formed in sandy soils under continuous arable cultivation without FYM were very unstable; they packed badly and were poorly permeable to water when they were slaked, and they formed strong clods when they were dried again.

Grass, and frequent applications of FYM, improved all of these attributes, though the effect of grass did not last long after ploughing. These results fall well into line with those of the work at Wellesbourne. The special soils on which strawy organic materials produce effects other than those associated with the supply of nutrients seem now to have been identified, and characterized, at least to a first approximation. On other soils, even such traditionally 'hungry' ones as the thin soils which overlie chalk and limestone, standard fertilizers supplemented in some rare instances by sources of minor elements, seem able to do all that is required.

\section{Discussion}

The last few years have seen a very considerable clarification of the complex of ideas which formerly surrounded, and one might even say obscured, the use in British agriculture of organic manures and their fellow-travellers, the grass leys. For the most part these do little but supply plant foods, though they may do this more efficiently, in some instances, than standard fertilizers. Their effects on the content of water-stable crumbs seem to have no more than limited general importance, though in particular circumstances they can be considerable. A special group of soils has been identified, however, on which strawy organic manures and grass, but not sewage sludge, have special importance because they can give a structure which is relatively stable, and will not so readily pack and become impermeable on wetting, or compact on drying. It is not organic matter as such that is important in this connexion but organic matter in particular forms, and the effect appears to be a perfectly respectable physical one.

These results should encourage a new look at the problem of soil organic matter in the developing countries, particularly in the tropics, where equilibrium contents of organic matter in arable soils are naturally low, and many soils compact severely in dry weather. Provided systems of soil management are used which can provide, in other ways, a higher degree of stability against erosion than organic matter can give, 
and can avoid compaction by appropriate and timely cultivations, fertilizers can do a great deal to raise yields in these areas, as the older fertilizer experiments in China and India (references in Bunting, 1962), and those more recently initiated under the Fertilizer Program of the Freedom From Hunger Campaign, have demonstrated. Indeed, we cannot hope to solve the world food problem unless we make considerable use of fertilizers. Our current knowledge of the mode of action of organic manures and of the effects of soil organic matter does not suggest that we need have any inhibitions about using fertilizers on soils of inherently low organic matter content, provided the technology of fertilizer use is carefully worked out. This may well be very different, particularly in respect of phosphate and liming, from the practice of temperate countries. With the limited human resources at our disposal for work of this kind, the main effort must be on this front. The information we have does not call for a major diversion of research effort to organic manuring in the tropics at the present time, particularly as the land needed to grow organic matter with which to make organic manures would in many countries be far better used, with the aid of fertilizer and improved agronomic practices, to grow crops. A large part of the basis of the use of FYM, in the older systems of husbandry in Britain, was the importation of plant foods in cattle feed from other countries. The situation in developing countries today is quite otherwise: they do not import plant foods from elsewhere in animal feeds. They should, and of course often do, return to the land the plant foods contained in crop residues, and in urban and domestic wastes, so far as this is consistent with human health. But even in China, where such wastes are carefully returned to the land, the use of fertilizers is essential to future progress.

\section{REFERENCES}

Bunting, A. H. (1962). Proc. Nutr. Soc. 21, 91.

Bunting, A. H. (1963). F. agric. Sci. 60, 121 .

Clement, C. \& Williams, T. E. (1965). F. agric. Sci. (In the Press.)

Cooke, G. W. (1963). Report of the Chemistry Department, in Rep. Rothamst. exp. Sta., 1962.

Cooke, G. W. \& Garner, H. V. (I954). F. R. agric. Soc. rr5, 27.

Empire Cotton Growing Corporation (1958). Progr. Rep. Exp. Stas Emp. Cott. Gr. Corp., season $1956-57$.

Empire Cotton Growing Corporation (1964). Progr. Rep. Exp. Stas Emp. Cott. Gr. Corp., season $1962-63$.

Haworth, F. (1960). Chemistry report, in Rep. nat. Veg. Res. Sta. Wellesbourne, I 959.

Haworth, F. \& Nelder, J. A. (1954). Rep. nat. Veg. Res. Sta. Wellesbourne, 1953, p. 30.

Haworth, F. \& Nelder, J. A. (1955). Rep. nat. Veg. Res. Sta. Wellesbourne, 1954, p. 40.

Salter, P. J. \& Haworth, F. (196r). F. Soil Sci. 12, 326.

Salter, P. J. \& Williams, J. B. (1963). F. Soil Sci, 14, 73.

Whitehead, D. C. (1963). Soils $\mathcal{E}^{\circ}$ Fert. 26, 217.

Williams, R. J. B. \& Cooke, G. W. (r96r). Soil Sci. 29, 30.

\section{The chemical composition of grasses in relation to agronomical practice}

\section{By R. WaIte, Hannah Dairy Research Institute, Ayr}

I should like first to consider the normal life cycle of a perennial grass growing without intervention by man, because the chemical composition of the grass utilized 